\title{
Inhaled Corticosteroid Treatment Regimens and Health Outcomes in a UK COPD Population Study [Corrigendum]
}

Bloom CI, Douglas I, Usmani OS, Quint JK. Int J Chron

Obstruct Pulmon Dis. 2020;15:701-710.

The authors have advised that there should be an added Funding section. The funding statement is as follows:

\section{Funding}

This study was funded by an Investigator Initiated Study from Chiesi. Chiesi had no role in the design, analysis, interpretation of findings or writing of the manuscript.

On page 709 the disclosure section should be presented as follows:

\section{Disclosure}

OSU and JKQ are co-last authors to this study. JKQ reports funding outside the submitted work from
AstraZeneca, Asthma UK, The Health Foundation, MRC, Wellcome Trust, BLF, GlaxoSmithKline, Insmed, Bayer, IQVIA, and Boehringer Ingelheim and funding from AstraZeneca, GlaxoSmithKline, Chiesi, Bayer, Teva, and Boehringer Ingelheim for Advisory board participation or travel. ID reports grants outside the submitted work from NIHR, GlaxoSmithKline, MRC, ABPI. OSU reports from outside the submitted work grants from AstraZeneca, Edmond Pharma and GlaxoSmithKline; personal fees from Aerocrine, Boehringer Ingelheim, Cipla, Mundipharma, Napp, Sandoz, Takeda and Zentiva. The authors report no other conflicts of interest in this work.

The authors apologize for these errors.
The International Journal of COPD is an international, peer-reviewed journal of therapeutics and pharmacology focusing on concise rapid reporting of clinical studies and reviews in COPD. Special focus is given to the pathophysiological processes underlying the disease, intervention programs, patient focused education, and self management protocols. This journal is indexed on PubMed Central, MedLine and CAS. The manuscript management system is completely online and includes a very quick and fair peer-review system, which is all easy to use. Visit http://www.dovepress.com/testimonials.php to read real quotes from published authors. 